Check for updates

The BMJ

Cite this as: $B M J 2021 ; 375: \mathrm{n} 2578$ http://dx.doi.org/10.1136/bmj.n2578 Published: 21 October 2021

\section{Covid-19: Government is "wilfully negligent" in not acting on rising numbers, says BMA}

\author{
Gareth lacobucci
}

The BMA has accused the UK government of being "wilfully negligent” by not immediately implementing additional precautionary measures to reduce the spread of covid-19.

At a Downing Street briefing on 20 October, England's health secretary, Sajid Javid, said that the government would not be bringing in its "plan B" measures to prevent health services being overwhelmed, including mandatory face coverings and working from home, "at this point.” This was despite the UK recording 49139 new covid cases, 179 deaths, and 869 hospital admissions on 20 October, and Javid warning that daily infection rates "could yet go as high as 100 ooo a day."

Javid said, "We'll do what it takes to make sure that this pressure doesn't become unsustainable and that we don't allow the NHS to become overwhelmed. Deaths remain mercifully low, but they are still sadly over 100 a day. This pandemic is not over.

"We're looking closely at the data, and we won't be implementing our plan B of contingency measures at this point. But we'll be staying vigilant, preparing for all eventualities.”

However, BMA's chair of council, Chaand Nagpaul, and the NHS Confederation urged the government to act now. ${ }^{1}$

“The Westminster government said it would enact 'plan B' to prevent the NHS from being overwhelmed," Nagpaul said. "As doctors working on the frontline, we can categorically say that time is now.

"The reality today is an unacceptable rate of infections, hospitalisations, and deaths, unheard of in similar European nations. It is wilfully negligent not to be taking any further action to reduce the spread of infection, such as mandatory mask wearing, physical distancing, and ventilation requirements in high risk settings, particularly indoor crowded spaces.”

Nagpaul said that the government had "taken its foot off the brake" and was in danger of repeating mistakes from previous waves of the pandemic. He warned, "We are rapidly approaching a position where, yet again, the government is delaying for too long and equivocating over taking action.

"This is the time to learn the lessons of the past and act fast, or else we will face far more extreme measures later."

Responding to a question asked at the briefing why the government was not acting now, Javid said, "Don't get me wrong, there are huge pressures, especially in A\&E, in primary care, for example. But at this point we don't believe they're unsustainable. If we feel at any point it's becoming unsustainable then we won't hesitate to act."

Javid emphasised the importance of people coming forward for vaccination, which he called the "primary line of defence" against the virus. He said, "If not enough people get their booster jabs, if not enough of those people that were eligible for the original offer ... if they don't come forward, if people don't wear masks when they really should in a really crowded place with lots of people that they don't normally hang out with, if they're not washing their hands, it's going to hit us all," he said.

"And it would of course make it more likely we're going to have more restrictions."

1 lacobucci G. Covid-19: Government must reintroduce precautionary measures now, say health leaders. BMJ2021;375:n2566.

This article is made freely available for use in accordance with BMJ's website terms and conditions for the duration of the covid-19 pandemic or until otherwise determined by BMJ. You may use, download and print the article for any lawful, non-commercial purpose (including text and data mining) provided that all copyright notices and trade marks are retained. 